\title{
ADDITIVITY OF VOLUME COMPONENTS OF TREE STEM
}

\author{
Alexandre Behling ${ }^{1}$, Hassan Camil David ${ }^{2}$, Clarice Garcia Borges Demétrio ${ }^{3}$, Carlos Roberto Sanquetta ${ }^{1}$, Ana \\ Paula Dalla Corte ${ }^{1}$, Antonio Pedro Fragoso Woycikievicz ${ }^{1 *}$ \\ ${ }^{1}$ Universidade Federal do Paraná, Programa de Pós-Graduação em Engenharia Florestal, Curitiba, Paraná, Brasil - \\ alexandre.behling@gmail.com; carlossanquetta@gmail.com; anapaulacorte@gmail.com; antoniof.w@gmail.com* \\ ${ }^{2}$ Universidade Federal Rural da Amazônia, Curso de Engenharia Florestal, Capitão Poço, Pará, Brasil - hassancamil@ gmail.com \\ ${ }^{3}$ Universidade de São Paulo, Departamento de Ciências Exatas, Piracicaba, São Paulo, Brasil - clarice.demetrio@usp.br
}

Received for publication: 11/04/2018 - Accepted for publication: 29/03/2019

\begin{abstract}
Resumo
Aditividade dos componentes do volume do fuste da árvore. O volume do fuste sem casca e o volume de sua casca são componentes do volume total do fuste. Portanto, uma característica essencial de equações de componentes é que elas sejam aditivas, ou seja, que ocorra compatibilidade das estimativas entre os componentes envolvidos com o seu total. Neste trabalho foram comparados dois procedimentos para a modelagem do volume total, volume do fuste sem casca e volume da casca. O primeiro procedimento (tradicional) consistiu em ajustar as equações de volume dos componentes e de seu total de maneira independente e o segundo em ajustar os três modelos por meio de um sistema de equações. A modelagem foi realizada para dados volumétricos da espécie acácia-negra (Acacia mearnsii De Wild.), utilizando um conjunto de 40 árvores. O segundo procedimento, com ajuste pelo método Weighted Nonlinear Seemingly Unrelated Regressions - WNSUR, garantiu condições para que os valores de volume estimados a partir das equações nãolineares dos componentes do fuste fossem compatíveis com os obtidos pela equação não-linear para o total e com menor variância, o que o torna mais apropriado em relação ao primeiro.

Palavras-chave: Nonlinear Seeming Unrelated Regressions, Heterocedasticidade, Equações não-lineares aditivas
\end{abstract}

\begin{abstract}
The stem volume without bark and the volume of the bark are components of the total stem volume. Therefore, an essential feature of equations of components is that they are additive, that is, that the compatibility of their estimates occurs between the components involved with their total. In this manuscript, two procedures were compared for modeling the total volume, stem volume without bark and bark volume. The first procedure (traditional) was to fit the equations of components of the volume and its total independently and the second to fit the three models by means of a system of equations. The modeling was performed from volume data of the black-wattle species (Acacia mearnsii De Wild.) using a set of forty trees. The second procedure, fitted by Weighted Nonlinear Seemingly Unrelated Regressions - WNSUR method, ensured that the volume estimates from non-linear equations of the stem components were compatibility with those the non-linear regressions for the total and with smaller variance, which makes it more appropriate method than the first one.

Keywords: Nonlinear Seemingly Unrelated Regressions, heteroscedasticity, additivity of nonlinear equations.
\end{abstract}

\section{INTRODUCTION}

In forest inventories, stem volume is one of the main variables of interest, mainly when it is obtained for commercial purposes. For several forest species, but especially for black-wattle (Acacia mearnsii De Wild.), there are at least two components of the stem volume that should be measured: inside-bark volume and bark volume. The black-wattle bark is the main source of tannin worldwide and its wood is an excellent raw material for pulp and paper production, among other purposes (Silva et al., 2017).

Quantifying forest resources depends on the nature of the components that may or not be additive, requiring that the modeling provides consistent results free of discrepancy between component values and total value. For the presented case of black-wattle, it is interesting that the estimates of the volume of components (stem without bark and bark) is compatible to the total volume, because in inventories is necessary to obtain the stocks of these components and these must be compatible to approach the biological reality.

The compatibility of the equations can be also called additivity, which corresponds to the volume estimates of stem components which do not differ from the total volume, i.e., the sum of the volume of the

FLORESTA, Curitiba, PR, v. 50, n. 1, p. 905 - 914, jan/mar 2020

Behling, A. et.al.

ISSN eletrônico 1982-4688

DOI: $10.5380 /$ rf.v50 i1.58875 
components should be equal to the total volume. When modeling the total volume and components, frequently, the fittings of the models are performed independently, that is, for each component a fitting is done without considering the interdependence that exists between the components of the tree and without considering the structuring of additive equations. Thus, when using them, the sum of the volumes of the components will not produce the same result as obtained by the total volume equation, consequently, is not biologically consistent.

Genet et al. (2011) specified 3 items (consistency, robustness and accuracy) for a good set of biomass equations, which can also be applied to the modeling of the volume. Specifically, this paper will address the first and the last. For these purposes, when fitting equations of total volume and volume of components, three fundamental aspects are defined: its performance, its consistency and its efficiency.

The common way of establishing equations for total volume and its components is to use a single equation (independent estimator) for each one of them. However, this has been a difficult task when evaluating the biological consistency and efficiency of the estimators. Although the additivity can be solved by taking the total biomass as the sum of the masses of the components, a better statistical efficiency remains expected, since the estimator is less efficient when compared to the application of the apparently unrelated regressions, a technique proposed in this research.

Additive equations are required for quality of the volume components of a tree and have been increasingly used. Recently, many researchers have been using the SUR (seemingly unrelated regressions) or NSUR (nonlinear seemingly unrelated regressions) methods in tree biomass modeling after the important contribution of Parresol (2001), when he carried out a review about these methods to obtain additive equations to estimate tree biomass. In Brazil, some approaches and applications about this subject were published by Sanquetta et al. (2014) and Sanquetta et al. (2015). In the present research, a new case was proposed to test the Paressol's procedures, in which additive equations are applied to components of the stem volume.

The idea of the method, according to the conceptions presented by Sanquetta et al. (2014) and Sanquetta et al. (2015) in research on biomass modeling, is:

i) For each component (inside-bark volume and bark volume) a model must be selected including the most appropriated independent variables,

ii) For the total volume the model is composed by the sum of equations proposed for the components mentioned above,

iii) The fitting of the models for the components and for the total must be soved independently, equation,

iv) A matrix must be composed with the variances and co-variances of the residuals of each fitted

v) A new fitting must be made with a simultaneously system of equations, whereby the variance and covariance matrix of the residuals is incorporated in such solution.

The additivity of the fitted models is obtained because the equation for the total volume is composed by the sum of the fitted equations for the components. The matrix of variances and co-variances of the residuals contributed to improve the efficiency of the method (reduction of the confidence interval of the mean estimate), as presented in the works of Sanquetta et al. (2014) and Sanquetta et al. (2015).

A question should be raised on how much of efficiency is achieved when applying of this method compared to the traditional method used in the forest companies for volume estimation. Also, it will be appropriated to evaluate the degree of incompatibility resulted by no achievement of additivity with the traditional modelling. This work aimed to test the proposed method and compare its results with those obtained by the traditional method used in forest companies for volume estimation.

\section{MATERIAL AND METHODS}

\section{Data description}

The research was carried out between January 2013 and January 2015, in five stands of black-wattle (Acacia mearnsii De Wild.) with 8 years (age at which the stands are harvested), located in the municipalities of Cristal, Encruzilhada do Sul and Piratini, state of Rio Grande do Sul, Brazil.

The following soil types were identified in the stands: Red -Yellow Dystrophic Argisol, Dystrophic Neosol and Greyish Argisol in the municipalities of Piratini, Encruzilhada do Sul and Cristal, respectively.

Two temporary plots were allocated in each stand and forty trees were selected randomly in these plots from the diameter distribution. Diameter at breast height and total height were measured in the plots and the stem volume was obtained applying the Smalian's method to each section, taking along the stem at the positions $0.1 \mathrm{~m}$, $0.3 \mathrm{~m}, 0.7 \mathrm{~m}, 1.3 \mathrm{~m}$ and subsequently at each meter up to reach the total height. The bark of the stem in these same sections were removed and new measurements of diameters at the same positions along the stem were taking. 
From this data, it was calculated the inside-bark volume, bark volume and total volume (inside-bark+ bark), as presented in Machado and Figueiredo Filho (2014).

Data analysis was performed using JULIA (https://julialang.org) and SAS (On Demand for Academics) software. The volume and confidence intervals (described in the sequence) were calculated using the JULIA language and the fit of the models using SAS.

\section{Equations for volume components of the stem}

The models selected to fit volume inside-bark, bark and total were:

$$
\begin{aligned}
& \mathrm{y}_{I B_{t}}=b_{11}\left(\frac{1}{d_{t}}\right)^{b_{12}} \mathrm{~h}_{t}^{b_{13}}+e_{t} \\
& \mathrm{y}_{B_{t}}=b_{21} \mathrm{~d}_{t}^{b_{22}}\left(\frac{1}{h_{t}}\right)^{b_{23}}+e_{t} \\
& y_{\text {Total }_{t}}=b_{31}\left(\frac{1}{d_{t}}\right)^{b_{32}} \mathrm{~h}_{t}^{b_{33}}+e_{t}
\end{aligned}
$$

Where: $y_{I B}$ is the steam volume without bark $\left(\mathrm{m}^{3}\right), \mathrm{y}_{B}$ is the bark volume $\left(\mathrm{m}^{3}\right), y_{\text {Total }}$ is the total volume, $d$ is the diameter at breast height $(\mathrm{cm}) h$ is the total height $(\mathrm{m}), b_{j k}$ are the coefficients of the model, $j$ refers to the coefficient of each equation and $k$ the coefficients between the equations and $t$ is an observation.

The models proposed in 1 to 3 are compositions of the Schumacher-Hall model. The inverse of the independent variables in the new set of equations contribute to reduce the effect of heteroscedasticity of the residuals. Also, other models were tested, such as the Berkhout $\left(y=\beta_{1} d^{\beta_{2}}\right)$, Honer $\left(y=d^{2}\left(\beta_{0}+\beta_{1} h^{-1}\right)^{-1}\right)$, Kopetzki $\left(y=\beta_{0}+\beta_{1} d^{2}\right)$, Meyer $\left(y=\beta_{1} d+\beta_{2} d^{2}\right)$, Spurr $\left(y=\beta_{0}\left(d^{2} h\right)^{\beta_{1}}\right)$ and Takata $\left(y=\left(d^{2} h\right)\left(\beta_{0}+\right.\right.$ $\left.\left.\beta_{1} d\right)^{-1}\right)$. Also, Berkhout, Spurr and Shumacher-Hall's models were linearized and fiitted by linear regression. The results of linear regression were similar to those obtained by non-linear regression, which is the reason we chose to use them in their original form.

The model selection for each component was based on the adjusted coefficient of determination $\left(R_{\text {adj }}^{2}\right)$ and standard error of estimate $\left(\mathrm{S}_{\mathrm{yx}}\right.$, in percentage), according to the conceptions presented by Steel, Torrie and Dickey (1996).

\section{Volume equations with independent estimates - Procedure 1}

Procedure 1 was defined as the traditional method used in the forest companies for volume estimation. In this method, each equation was fitted independently. The models were fitted by generalized nonlinear least squares - GNLS (GREENE, 2008). White's test - W (1980) was applied to test the hypothesis of homogeneity of residues for each equation, with $95 \%$ probability. This hypothesis was rejected, therefore weights were obtained using the variances structure, as defined in Harvey (1976) and Parresol (2001), followed by the new fitting of the equation and new application of the White's test and evaluation of the residuals' scatter plots.

The authors believe that it is important to present the variance-covariance matrices, since they are useful to make several inferences, which will be presented in the following sections. Also, other assumptions of regression analysis were tested (autocorrelation and normality of the residuals), but these results were not presented in the manuscript, therefore the efficiency of the regression estimator depends on the variance.

\section{Systems of volume equations - Procedure 2}

The model for the total volume was considered as a function of the independent variables of the equations for each component $i$, for the $t^{\text {th }}$ observation. This is presented in (4) to (6):

$$
\begin{aligned}
& \mathrm{y}_{I B_{t}}=b_{11}\left(\frac{1}{d_{t}}\right)^{b_{12}} \mathrm{~h}_{t}^{b_{13}}+e_{I B_{t}} \\
& \mathrm{y}_{B_{t}}=b_{21} d_{t}^{b_{22}}\left(\frac{1}{h_{t}}\right)^{b_{23}}+e_{B_{t}} \\
& \mathrm{y}_{\text {Total }_{t}}=b_{11}\left(\frac{1}{d_{t}}\right)^{b_{12}} \mathrm{~h}_{t}^{b_{13}}+b_{21} d_{t}^{b_{22}}\left(\frac{1}{h_{t}}\right)^{b_{23}}+e_{\text {Total }_{t}}
\end{aligned}
$$

This system of equations was fitted by nonlinear seemingly unrelated regressions - NSUR, with definitions of estimators in Srivastava and Giles (1987), Greene (2008) and Parresol (2001). When the hypothesis for the homogeneity of residuals was rejected, the weights obtained in Procedure 1 were applied to get a new fitting of the system of equations using weighted-nonlinear seemingly unrelated regressions - WNSUR.

FLORESTA, Curitiba, PR, v. 50, n. 1, p. 905 - 914, jan/mar 2020 
The matrix of variance-covariance shows the correlations between the components obtained in the same tree. The correlation of the components in the same tree is expressed by this matrix (for both it is possible to transform its covariances to obtain the correlation matrix), and these correlations express the gains in efficiency in the confidence intervals (as described in the sequence), owing to the application of WNSUR method. This correlation is included in the parameter estimates only in procedure 2 and, consequently, in the calculation of the variance of the estimate. If the components are correlated, then there is a reduction in the estimate of the confidence interval, occurring proportionally, i.e., the more correlated are the components also will be the reduction of the confidence interval. These matrices were included because this information is necessary to do the confidence intervals of the estimates.

\section{Compatibility of volume component estimates, performance and efficiency of Procedure 1 and 2}

The compatibility of volume component estimates was assessed to evaluate the additivity. Estimates of volume were considered compatible if $\hat{y}_{\text {Total }}=\hat{y}_{I B}+\hat{y}_{B}$. If this condition is not satisfied, then the volume estimates are not compatible.

The performance of the equations for total volume and for the components obtained in Procedure 1 and Procedure 2 were compared using the values of the coefficients of determination and standard error of estimate. There are other statistics to evaluate the performance of the equations (prediction sum of squares - PRESS, Akaike's information criterion - AIC, Bayesian information criterion - BIC, Amemiya's prediction criterion APC and information complexity criterion - ICC), but they will not reveal what procedure is better, because Procedure 1 and Procedure 2 have the same objective: minimize the sum of squares of the residuals.

Difference between the procedures can be evaluated preferable by the confidence intervals of the estimates. In Procedure 1, the equations are fitted independently. In Procedure 2, a simultaneously system of equations is fitted, whereby the variance and co-variance matrix of the residuals is incorporated in such solution. Hence it is important to evaluate if the inclusion of this matrix contributes to reach smaller mean variance of estimates.

The efficiency of the estimators of the volume equations fitted by means of procedures 1 and 2 can be evaluated by the precision of confidence intervals in (7).

$$
P C I_{t}=\frac{C I_{i}}{\hat{y}_{i}}
$$

Where: $P C I_{t}$ is the precision of the confidence interval for the $t^{\text {th }}$ observation of the $i^{\text {th }}$ component; $C I_{i}$ is the confidence interval for the $t^{t h}$ observation of the $i^{t h}$ component; $\hat{y}_{i}$ is the estimated value for the $t^{t h}$ observation of the predictor variables.

The confidence intervals for Procedure 1 were calculated according to Greene (2008) and for Procedure 2 as presented in Parresol (2001).

\section{RESULTS}

Volume equations with independent estimates - Procedure 1

Using Procedure 1 the equations (8) to (10) were obtained:

$$
\begin{aligned}
& \hat{y}_{I B_{t}}=0.000057\left(\frac{1}{d_{t}}\right)^{-1.99149} h_{t}^{0.810823} \\
& \mathrm{R}^{2}{ }_{\text {adj }}=97.37 \%, \mathrm{~S}_{\mathrm{yx}}=14.45 \%, \mathrm{~W}=36.08^{*} \\
& \hat{y}_{B_{t}}=5.735 e^{-7} d_{t}^{1.457641}\left(\frac{1}{h_{t}}\right)^{-2.29091} \\
& \mathrm{R}^{2}{ }_{\text {adj }}=95.20 \%, \mathrm{~S}_{\mathrm{yx}}=21.83 \%, \mathrm{~W}=26.03 * \\
& \hat{y}_{\text {Total }}=0.00047\left(\frac{1}{d_{t}}\right)^{-1.91816} h_{t}^{1.003929} \\
& \mathrm{R}^{2}{ }_{\text {adj }}=97.88 \%, \mathrm{~S}_{\mathrm{yx}}=12.95 \%, \mathrm{~W}=36.02 *
\end{aligned}
$$

The weights $\left(\varepsilon_{i_{t}}^{2}\right)$ were obtained after fitting the models, which resulted the weighted functions for stem volume without bark (IB), bark volume (B) and total volume (Total) presented in (10) to (12):

$$
\begin{aligned}
& \varepsilon_{\mathrm{IB}_{t}}^{2}={\frac{1}{d_{t}}}^{-5.32099} h_{t}^{-6.65224} \\
& \varepsilon_{B_{t}}^{2}=d_{t}^{2.61179} \frac{1^{-2.49629}}{h_{t}} \\
& \varepsilon_{\text {Total }_{t}}^{2}={\frac{1}{d_{t}}}^{-4.33314} h_{t}^{-4.79224}
\end{aligned}
$$


The statistics of the fitted weighted equations by procedure 1 are presented in (13) to (15):

$$
\begin{aligned}
& \hat{y}_{I B_{t}}=0.000053\left(\frac{1}{d_{t}}\right)^{-2.11544} h_{t}^{0.715924} \\
& \mathrm{R}^{2}{ }_{\text {adj }}=97.34 \%, \mathrm{~S}_{\mathrm{yx}}=15.08 \%, \mathrm{~W}=12.67^{\mathrm{ns}} \\
& \hat{y}_{B_{t}}=1.503 \mathrm{e}-6 d_{t}^{1.655778}\left(\frac{1}{h_{t}}\right)^{-1.77246} \\
& \mathrm{R}^{2}{ }_{\text {adj }}=94.87 \%, \mathrm{~S}_{\mathrm{yx}}=19.53 \%, \mathrm{~W}=11.67^{\mathrm{ns}} \\
& \hat{y}_{\text {Total }}=0.000046\left(\frac{1}{d_{t}}\right)^{-2.04728} h_{t}^{0.884656} \\
& \mathrm{R}^{2}{ }_{\text {adj }}=97.71 \%, \mathrm{~S}_{\mathrm{yx}}=13.47 \%, \mathrm{~W}=12.65^{\mathrm{ns}}
\end{aligned}
$$

The correction of heteroscedasticity was evidenced (Figure 1), and all coefficients were significant at $95 \%$ probability by application of the $t$-test. The adjusted coefficients $b_{\mathrm{j} 1}$ without weight were not significant.

\section{Systems of volume equations - Procedure 2}

The system of equations fitted by NSUR is presented in (16) to (18):

$$
\begin{aligned}
& \hat{y}_{I B_{t}}=0.00004\left(\frac{1}{d_{t}}\right)^{-1.91791} h_{t}^{1.004076} \\
& \mathrm{R}^{2}{ }_{\text {adj }}=97.43 \%, \mathrm{~S}_{\mathrm{yx}}=14.96 \%, \text { White }=34.47 * \\
& \hat{y}_{B_{t}}=6.666 e^{-6} d_{t}^{1.917826}\left(\frac{1}{h_{t}}\right)^{-1.00434} \\
& \mathrm{R}^{2}{ }_{\text {adj }}=93.69 \%, \mathrm{~S}_{\mathrm{yx}}=21.83 \%, \text { White }=36.67 * \\
& \hat{y}_{\text {Total }_{t}}=0.00004\left(\frac{1}{d_{t}}\right)^{-1.91791} h_{t}^{1.004076}+6.666 e^{-6} d_{t}^{1.917826}\left(\frac{1}{h_{t}}\right)^{-1.00434} \\
& \mathrm{R}^{2}{ }_{\text {adj }}=97.88 \%, \mathrm{~S}_{\mathrm{yx}}=12.95 \%, \text { White }=36.02 *
\end{aligned}
$$

Where: $*$ significant at $95 \%$ probability level according to the Chi-square test.

Heteroscedasticity was confirmed as occurred in the previous cases evaluated in Procedure 1. The statistics of the fitted weighted system of equations by procedure 2 (WNSUR) are presented in (19) to (21).

$$
\begin{aligned}
& \hat{y}_{I B_{t}}=0.000037\left(\frac{1}{d_{t}}\right)^{-2.05926} h_{t}^{0.896773} \\
& \mathrm{R}^{2} \text { adj }=97.34 \%, \mathrm{~S}_{\mathrm{yx}}=14.71 \%, \mathrm{~W}=12.01^{\mathrm{ns}} \\
& \hat{y}_{B}=1.481 e^{-6} d_{t}^{1.799207}\left(\frac{1}{h_{t}}\right)^{-1.64946} \\
& \mathrm{R}^{2}{ }_{\text {adj }}=93.93 \%, \mathrm{~S}_{\mathrm{yx}}=21.09 \%, \mathrm{~W}=11.59^{\mathrm{ns}} \\
& \hat{y}_{\text {Total }}=0.000037\left(\frac{1}{d_{t}}\right)^{-2.05926} h_{t}^{0.896773}+1.481 e^{-6} d_{t}^{1.799207}\left(\frac{1}{h_{t}}\right)^{-1.64946} \\
& \mathrm{R}^{2} \text { adj }=97.67 \%, \mathrm{~S}_{\mathrm{yx}}=13.59 \%, \mathrm{~W}=11.89^{\mathrm{ns}}
\end{aligned}
$$

The correction of heteroscedasticity was evidenced (Figure 1), and all coefficients were significant at $95 \%$ probability by application of the $t$-test. The adjusted coefficients $b_{\mathrm{j} 1}$ without weight were not significant.

The variance-covariance matrix of $b_{j k}$ (where $j$ refers to the coefficient of each equation and $k$ the coefficients between the equations) is presented in (22).

\begin{tabular}{c|cccccc}
$\widehat{\Sigma}_{b}=$ & $b_{11}$ & $b_{12}$ & $b_{13}$ & $b_{21}$ & $b_{22}$ & $b_{23}$ \\
$b_{11}$ & $3.04300 \mathrm{E}-10$ & $-8.46900 \mathrm{E}-07$ & $-3.64100 \mathrm{E}-06$ & $2.99000 \mathrm{E}-12$ & $5.83910 \mathrm{E}-07$ & $1.23110 \mathrm{E}-06$ \\
$b_{12}$ & $-8.46900 \mathrm{E}-07$ & $5.60680 \mathrm{E}-03$ & $1.31700 \mathrm{E}-02$ & $-1.37500 \mathrm{E}-08$ & $-3.77240 \mathrm{E}-03$ & $-6.71310 \mathrm{E}-03$ \\
$b_{13}$ & $-3.64100 \mathrm{E}-06$ & $1.31700 \mathrm{E}-02$ & $4.64240 \mathrm{E}-02$ & $-4.08900 \mathrm{E}-08$ & $-9.01380 \mathrm{E}-03$ & $-1.78379 \mathrm{E}-02$ \\
$b_{21}$ & $2.99000 \mathrm{E}-12$ & $-1.37500 \mathrm{E}-08$ & $-4.08900 \mathrm{E}-08$ & $3.55900 \mathrm{E}-13$ & $4.37270 \mathrm{E}-08$ & $1.24040 \mathrm{E}-07$ \\
$b_{22}$ & $5.83910 \mathrm{E}-07$ & $-3.77240 \mathrm{E}-03$ & $-9.01380 \mathrm{E}-03$ & $4.37270 \mathrm{E}-08$ & $1.43499 \mathrm{E}-02$ & $2.35293 \mathrm{E}-02$ \\
$b_{23}$ & $1.23110 \mathrm{E}-06$ & $-6.71310 \mathrm{E}-03$ & $-1.78379 \mathrm{E}-02$ & $1.24040 \mathrm{E}-07$ & $2.35293 \mathrm{E}-02$ & $5.09413 \mathrm{E}-02$
\end{tabular}


The variance-covariance matrix of residuals $(\hat{\sigma})$ is presented in $(23)$ :

\begin{tabular}{r|ccc}
$\hat{\sigma}=$ & IBV & BV & Total \\
IBV & $1.2956 \mathrm{E}-02$ & $4.3403 \mathrm{E}-08$ & $6.1175 \mathrm{E}-03$ \\
$\mathrm{BV}$ & $4.3403 \mathrm{E}-08$ & $2.1930 \mathrm{E}-11$ & $9.4155 \mathrm{E}-08$ \\
Total & $6.1175 \mathrm{E}-03$ & $9.4155 \mathrm{E}-08$ & $3.1651 \mathrm{E}-03$
\end{tabular}

Using this matrix $(\hat{\sigma})$, it is possible to obtain the correlations between the components on the same tree (transformed variance-covariance matrix to correlations matrix). These correlations express the degree of efficiency of the confidence intervals due to the application of Procedure 2.
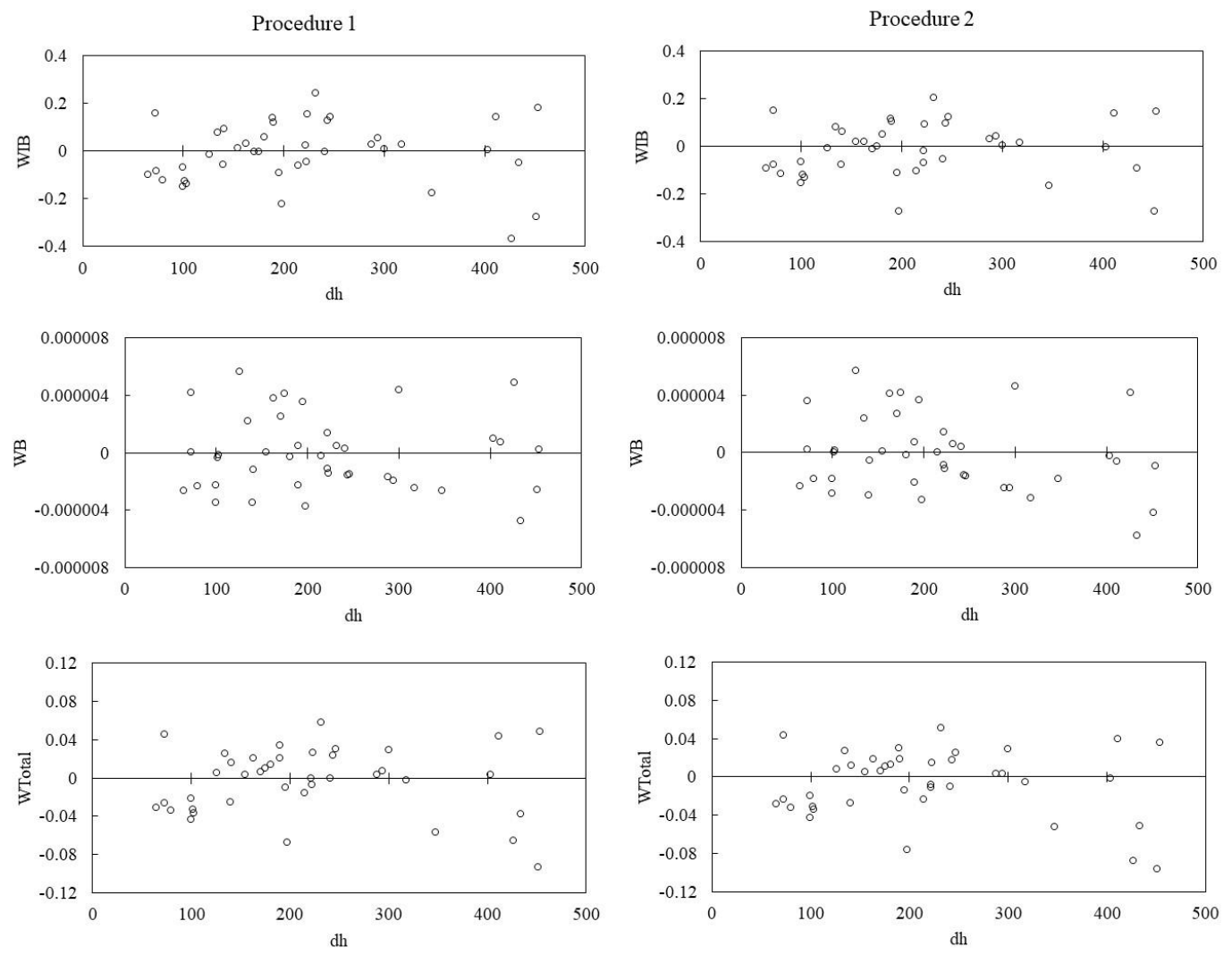

Figure 1 - Weighted residuals to volume components and total volume equations fitted by means of procedure 1 and 2, observed in forest stands of black wattle species in the state of Rio Grande do Sul.

Figura 1 - Resíduo ponderado para o volume dos components e volume total das equações ajustadas por meio dos procedimentos 1 e 2, obtidos em povoamentos da espécie acácia negra no estado do Rio Grande do Sul.

Where: $W I B$ is the residue weighted for stem volume without bark, $W B$ is the residue weighted for bark volume, WTotal is the residuals for total volume and $d h$ ( $d$ is the diameter at breast height and $h$ is the height).

\section{Compatibility of volume components estimates, performance and efficiency of Procedures 1 and 2}

The restriction of compatibility estimation, i.e., $\hat{y}_{T_{\text {otal }}}=\hat{y}_{I B_{t}}+\hat{y}_{B_{t}}$ was not observed only for the equations fitted by means of procedure 1 . Therefore, as $\hat{y}_{T_{\text {otal }}}-\hat{y}_{I B_{t}}-\hat{y}_{B_{t}} \neq 0$, this equation was considered not compatible. The non-additivity of this equation given by $Y_{I}$, i.e., $\hat{Y}_{I_{t}}=\hat{y}_{\text {Total }_{t}}-\hat{y}_{I B_{t}}-\hat{y}_{B_{t}}$, at tree level is shown in Figure 2 for the variable $d$ and $h$ respective results in percentage $\left(Y_{I R}\right)$ for the variable bark volume $\left(Y_{I R_{t}}=\frac{\hat{Y}_{I_{t}}}{\hat{y}_{B_{t}}}\right)$. 

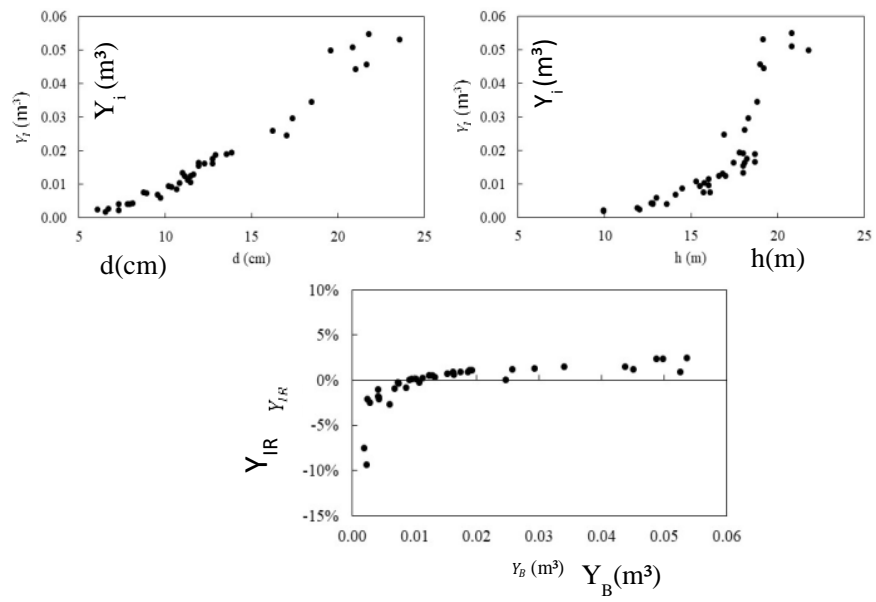

Figure 2 - Non-additivity estimates of volume components, derived from equations fitted by means of procedure 1 , at tree level, observed in forest stands of black wattle species in the state of Rio Grande do Sul.

Figura 2 - Não aditividade das estimativas dos volumes dos components, derivados das equações ajustadas por meio do procedimento 1, a nível de árvores, obtida em povoamentos da espécie acácia negra no estado do Rio Grande do Sul.

Where: $Y_{I}$ is the lack of compatibility, in $\mathrm{m}^{3}$, given by $\hat{Y}_{I_{t}}=\hat{y}_{T o t a l_{t}}-\hat{y}_{I B_{t}}-\hat{y}_{B_{t}}$ e $Y_{I R}$ are the respective results in percentage, given by $\hat{Y}_{I R_{t}}=\hat{Y}_{I_{t}} / \hat{y}_{B_{t}} ; d$ is the diameter at breast height in $\mathrm{cm} ; h$ is the height in $\mathrm{m}$ e $Y_{B}$ is the bark volume in $\mathrm{m}^{3}$.

The statistics for assessment of the fitting quality, $\mathrm{R}^{2}$ adj and $S_{y x}$, for the volume equations of the components and total, fitted by means of the procedures 1 and 2 , showed similar results in behavior (compare the results presented in section volume equations with independent estimates - Procedure 1 and systems of volume equations - Procedure 2). Still, tendency among the observed and estimated values by procedures 1 and 2 were not observed. The equations fitted by means of procedure 2 were more efficient than those obtained by procedure 1 , owing to the smaller associated standard error, consequently lower confidence interval (Figure 3). This better performance, both for volume of the components as well as for total volume was expected, since they provided estimates with smaller variance, owing to the higher correlation between the components of the tree. For the component stem volume without bark, the mean precision $\left(\hat{Y}_{i_{t}}\right)$ of the confidence interval was $46.18 \%$ for Procedure 1 and $39.05 \%$ for procedure 2 . For the bark volume, the precision was $12.07 \%$ for the Procedure 1 and $6.19 \%$ for Procedure 2. For the total volume, precision was $41.57 \%$ for Procedure 1 and $33.19 \%$ for Procedure 2. The better precisions obtained in Procedure 2 as compared to those obtained in Procedure 1, was also observed in the prediction intervals. This indicates that the most efficient strategy is to fit volume equations by seemingly unrelated regressions.

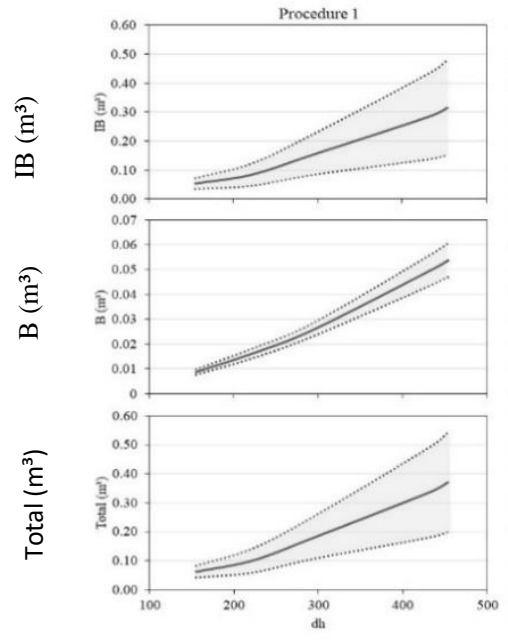

$\mathrm{dh}$

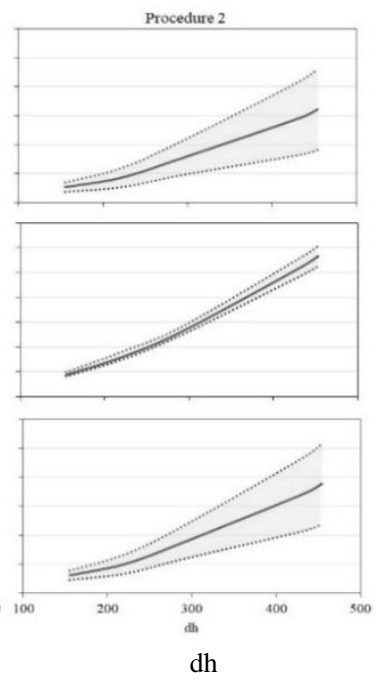

$\mathrm{dh}$

FLORESTA, Curitiba, PR, v. 50, n. 1, p. 905 - 914, jan/mar 2020

Behling, A. et.al.

ISSN eletrônico 1982-4688

DOI: $10.5380 /$ rf.v50 i1.58875 
Figure 3 - Confidence intervals for volume components and total volume equations fitted by means of procedure 1 and 2, observed in forest stands of black wattle species in the state of Rio Grande do Sul.

Figura 3 - Intervalos de confiança para o volume dos components e volume total ajustados por meio dos procedimentos 1 e 2, obtidos em povoamentos da espécie acácia negra no estado do Rio Grande do Sul.

Where: $I B$ is the stem volume without bark $B$ is the bark volume, WTotal is the total volume and $d h(d$ is the diameter at breast height and $h$ is the height).

\section{DISCUSSION}

The models selected to estimate the volume of the components are appropriate, since the statistics to evaluate the quality of model fitting were satisfactory.

The detection of heteroscedasticity of the residuals in volume estimation was already expected in this research. The volume variability of trees with smaller diameters is smaller than the volume variability of trees of larger diameters, causing the inconsistent variance in the errors of the biomass equations. Therefore, there was a proportionality of the variance in relation to the mean, that is, the values of the volume residuals in relation to their mean increase from the smaller classes of $d$ or $h$ to the larger ones.

Overestimation and underestimation of the variance of the error depends on the size of the trees. The application of the weights allowed achieving the homoscedasticity, which was detected by the White test. Therefore, the obtained statistics can be safely used to perform inferences, especially in confidence and prediction intervals.

The performance of the equations for some statistics produced by the equations fitted through procedure 2 , led to a small improvement and to others not, that is, a small difference was observed, which does not affect the estimates. This is a direct effect of the flexibility of the estimator to meet the additivity condition of the components.

An essential characteristic of equations of components is that they should be additive, i.e. estimations of the involved component values and the total values should be compatible between them, $\hat{y}_{\text {Total }}=\hat{y}_{I B_{t}}+\hat{y}_{B_{t}}$. When Kozak (1970) presented such theory in forestry, he emphasized that the additivity in systems of equations ensures consistency between its components. Thus, the equations obtained by WNSUR are consistent, revealing the compatibility between the volume components and its total volume, which was not observed in Procedure 1.

Such evidence is undesirable because if the tree components compose the whole tree, it is expected that their estimates when added should be equal to the total. The lack of additivity causes inconsistency in the total volume estimation and the discrepancy becomes even worse when the volume estimation is extrapolated to the total area of the forest stand or even to larger areas.

The inclusion of contemporaneous correlations between the volume of components and total volume [given by the variance-covariance matrix in (23)], in the fitting of the equation systems by procedure 2 , resulted in more accurate confidence intervals (Figure 3), thus evidencing one of its most important properties, efficiency. The equations adjusted through procedure 1 do not consider contemporary correlations, which impairs the efficiency of this estimator.

The system modeling structure of equations, given by procedure 2, was used to guarantee the property of the additivity for nonlinear volume models. The proposed system ensured additive equations and, through the inclusion of the error variance in the structure adjustment of functions, obtaining minimum variance estimates. Modelling components ensures many positive contributions in Forest Science, which can be found in research developed by Kozak (1970), Cunia (1979), Parresol (2001), Menéndez-Miguélez et al. (2013), Bi et al. (2015), Tesfaye et al. (2016), Sanquetta et al. (2015), Zheng et al. (2015) and Affleck and Diéguez-Aranda et al. (2016). These authors emphasize the importance of establishing additive equations, when compared with the independent fittings. The main positive points that should be highlighted are additivity of equations; gain on quality fitting; reduction of standard errors of the coefficients and of the variance of the mean.

The reduction of the confidence and prediction intervals is consequence of a smaller variance obtained by the application NSUR methods (Figure 3), owing to the inclusion of the contemporary correlation between the residuals of the related equations. This is a very important application in quantification and economic analysis of forest resources in forest management planning, for the following reasons: i) volume estimates and equation adjustment statistics similar to the method that maximizes the quality of the independently adjusted equation, ii) the volume equations of the components are additive to compose the total volume equation, and iii) volume and coefficients with lower variance, therefore more efficient.

In forestry, most of the researches addressing on the additivity of equations is focused on biomass estimation and, curiously, other applications are scarce, distinguishing the authors Rose and Lynch (2001), that modeled basal area growth and surveys using SUR, and the works of Rodríguez, Lizarralde and Bravo (2013), and 
Krisnawati (2016) applied to taper functions of Corsican Pine and Acacia mangium using NSUR and SUR, respectively. In modelling of taper functions, most of the researches addressed on compatibility of merchantable stem volume and taper equation, as Tang et al. (2016) and Zheng et al. (2017),

In this research, we have applied WNSUR for modelling stem volume without bark, bark volume and total volume. The results provided more efficient and compatible equations, as we expected. We hope that this manuscript may be useful for better understanding of basic principles for application of the WNSUR method and its analytical procedures. However, we recommend that the references cited in this manuscript are consulted for better understanding the statistic theory underlying this method.

\section{CONCLUSIONS}

- The estimation of the stem total volume and volume of the components in independent estimations should not be treated separately. The better procedure to model tree total volume and volume of its components should consider the interdependence of components by applying simultaneous fitting.

- The system of equations for modeling the total volume and their volume components provides advantages, mainly because the compatibility between them, besides obtaining more efficient parameters.

- The weighted system of equations influenced the quality of fit of the equation; however, it allows archiving the homogeneity of the residuals, a desirable property.

- The system of equations assures best conditions to fit allometric equations for total volume and their volume components, when compared to independent estimation, therefore encouraging the application of this method.

\section{Acknowledgements:}

The authors thank the TANAGRO S.A company for cession of the data and CNPq for granting a scholarship to one of the authors. Also, thanks are made to the reviewers for the appropriated suggestions on this manuscript.

\section{REFERENCES}

AFFLECK, D.L.R.; DIÉGUEZ-ARANDA, U. Additive nonlinear biomass equations: a likelihood-based approach. Forest Science, v. 62, n. 2, p. 129-140, 2016.

BI, H.; MURPHY, S.; VOLKOVA, L.; WESTON, C.; FAIRMAN, T.; LI, Y.; LAW, R.; NORRIS, J.; LEI, X.; CACCAMO, G. Additive biomass equations based on complete weighing of sample trees for open eucalypt forest species in south-eastern Australia. Forest Ecology and Management, v. 349, p. 106-121, 2015.

CUNIA T. On tree biomass tables and regression: some statistical comments. In: Frayern W.E. Forest resource inventory workshop proceedings. Fort Collins: Ed. Dept. of Forest and Wood Sciences, 1979, 1037 p.

GENET, A.; WERNSDÖRFER, H.; JONARD, M.; PRETZSCH, H.; RAUCH, M.; PONETTE, Q.; NYS, C.; LEGOUT, A.; RANGER, J.; VALLET, P.; SAINT-ANDRÉ, L. Ontogeny partly explains the apparent heterogeneity of published biomass equations for Fagus sylvatica in central Europe. Forest Ecology and Management, v. 261, n. 7, p. 1188-1202, 2011.

GREENE, W.H. Econometric analysis. Upper Saddle River: Prentice-Hall, 2008. 1178p.

HARVEY, A. C. Estimating regression models with multiplicative heteroscedasticity. Econometrics. Basel, v. 44, p. $461-465,1976$.

KOZAK, A. Methods of ensuring additivity of biomass components by regression analysis. The Forestry Chronicle. Mattawa, v. 46, p. 402 - 404, 1970.

KRISNAWATI, H. A compatible estimation model of stem volume and taper for acacia mangium willd. Plantations. Indonesian Journal of Forestry Research. Pulau Fordate, v. 3, n. 1, p 49 - 64, 2016.

MACHADO, S.A.; FIGUEIREDO FILHO, A. Dendrometria. Guarapuava: Unicentro, $2^{\mathrm{a}}$ ed. 2014. 316p.

MENÉNDEZ-MIGUÉLEZ, M.; CANGA, E.; BARRIO-ANTA, M.; MAJADA, J.; ÁLVAREZ-ÁLVAREZ, P. A three level system for estimating the biomass of Castanea sativa Mill. coppice stands in north-west Spain. Forest Ecology and Management, Fort Collins, v. 291, p. 417- 426, 2013.

FLORESTA, Curitiba, PR, v. 50, n. 1, p. 905 - 914, jan/mar 2020

Behling, A. et.al.

ISSN eletrônico 1982-4688

DOI: $10.5380 /$ rf.v50 i1.58875 
PARRESOL, B.R. Additivity of nonlinear biomass equations. Canadian Journal of Forest Research. Québec, V. 31, p. $865-878,2001$.

RODRÍGUEZ, F.; LIZARRALDE, I.; BRAVO, F. Additivity on nonlinear stem taper functions: a case for corsican pine in northern Spain. Forest Science. Washington, v. 59, p. $464-471,2013$.

ROSE, C.E.; LYNCH, T. B. Estimating parameters for tree basal area growth with a system of equations and seemingly unrelated regressions. Forest Ecology and Management. Fort Collins, v. 148, p. 51 - 61, 2001.

SANQUETTA, C. R.; BEHLING, A.; CORTE A. P. D.; RUZA, M. S.; PSCHEIDT, H. Estoques de biomassa e carbono em povoamentos de acácia-negra em diferentes idades no Rio Grande do Sul. Scientia Forestalis. Piracicaba, v. 42, p. 1 - 10, 2014.

SANQUETTA, C. R.; BEHLING, A.; CORTE, A. P. D.; PÉlliCO NETTO, S.; SCHIKOWSKI, A. B.; AMARAL, M. Simultaneous estimation as alternative to independent modeling of tree biomass. Annals of Forest Science. Nancy, v. 72, p. $1099-1112,2015$.

SILVA, D. A.; BEHLING, A.; SANQUETTA, C. R,; CORTE, A. P. D.; RUZA, M. S.; PSCHEIDT, H.; COSTA JUNIOR, S. . Potencial dendroenergético dos diferentes compartimentos de Acacia mearnsii cultivada no estado do Rio Grande do Sul. BIOFIX Scientific Journal, v. 2, n. 2, p. 71-75, 2017

SRIVASTAVA, V.K.; GILES, D.E.A. Seemingly Unrelated Regression Equations Models. Estimation and Inference. New York: Marcel Decker, 1987. 374 p.

STEEL, R. G. D.; TORRES, J. H.; DICKEY, D. A. Principles and procedures of statistics: a biometrical approach. New York: Ed. McGraw-Hill, 1996, 672 p.

TANG, X.; PÉREZ-CRUZADO, C.; FEHRMANN, L. ÁLVAREZ-GONZÁLES, J. G.; LU, Y.; KLEINN, C. Development of a Compatible Taper Function and Stand-Level Merchantable Volume Model for Chinese Fir Plantations. Plos One. State College, v. 11, n. 1, p. 1 - 15, 2016.

TESFAYE, M.A.; BRAVO-OVIEDO, A.; BRAVO, F.; RUIZ-PEINALDO, R. Aboveground biomass equations for sustainable production of fuelwood in a native dry tropical afro-montane forest of Ethiopia. Annals of Forest Science, v. 73, p. 411 - 423, 2016.

WHITE, H. A. Heteroskedasticity consistent covariance array estimator and a direct test of heteroskedasticity. Econometrics. Basel, v. 48, p. 817 - 838, 1980.

ZHENG, C.; MASON, E.G.; JIA, L.; WEI, S.; SUN, S.; DUAN, J. A single-tree additive biomass model of Quercus variabilis Blume forest in North China. Trees, v. 29, n. 3, p. 705- 716, 2015.

ZHENG, C.; WANG, Y.; JIA, L.; WE, S.; SUN, C.; DUAN, J. Compatible taper-volume models of Quercus variabilis Blume forests in north China. iForest - Bio geosciences and Forestry. Firenzi, v. 10, p. 567 - 575, 2017. 